\title{
Dealing with emotions. A Pedagogical Chal- lenge to Innovative Learning
}

\author{
Camilla Schmidt, lektor, Institut for Mennesker og Teknologi, Roskilde \\ Universitet
}

Birthe Lund og Tatiana Chemi (Eds.)

Sense Publishers, 2015

136 sider

ISBN 978-94-6300-064-2

Bogen består af kapitler (eller separate artikler) med en indledning og afsluttende konklusion forfattet af redaktørerne, samt et såkaldt 'afterword' af en syvende forfatter. Bogen er skrevet på engelsk. Det erklærede formål med bogen er at adressere et tabu omkring at beskæftige sig med 'emotions' (følelser) i uddannelsessammenhænge. Forfatterne mener, at der i uddannelsessammenhæng er en manglende bevidsthed om, hvordan følelser integreres som en del af undervisningen i praksis, og hvordan følelser er på spil i uddannelse i bredere forstand. Gennem belysning af en række forskellige uddannelsesog undervisningsmæssige sammenhænge i grundskole, ungdomsuddannelse, videregående uddannelse og voksenuddannelse, nationalt og internationalt, diskuteres forståelser af følelser i uddannelse og læring.

Kapitlerne i bogen er alle forfattet af medlemmer af en forskningsgruppe ved Ålborg Universitet, som arbejder med at udvikle og udbrede viden om eksisterende læringskulturer og nye tendenser inden for uddannelse. Gruppen beskæftiger sig især med innovativ læring, kreativ læring, brugen af kunst i undervisningen, formelle og uformelle læringskulturer, evaluering og bedømmelse i grundskolen, problembaseret læring og projektarbejde i ungdomsuddannelser og udvikling af læringskulturer i videregående uddannelse og voksenuddannelse. Det er også inden for disse områder, kapitlerne i bogen tager deres afsæt i arbejdet med følelser i uddannelse, idet der argumenteres for, at sådanne læringskulturer i særlig grad gør det muligt at få øje på og arbejde med følelser.

Det er ikke klart, hvem målgruppen for bogen er. Forfatterne giver ikke selv noget bud på, hvem målgruppen kan være. Der lægges i stedet vægt på, at bogen har som mål at reflektere over, hvordan følelser viser sig, og hvilken betydning de kan have i uddannelse ud fra såvel teoretiske refleksioner som empiriske nedslag. Bogen henvender sig således nok bredt til undervisere og uddannelsesforskere med et budskab om at reflektere følelsesmæssige aspekter af undervisningen samt om at forholde sig til, hvordan der kan arbejdes med teoretiske perspektiver på følelser i uddannelser.

Alle kapitlerne i bogen er hver i sær interessante og leverer nogle tankevækkende analyser, som alle har at gøre med, hvordan følelser er på spil i uddannelsessammenhæenge. Det bliver dog aldrig helt klart, hvordan kapitlerne hænger sammen, og hvordan de refererer til hinanden. De har tydeligt afsæt i en interesse i læringskulturer, som også er forskningsgruppens erklærede interessefelt.

Som uddannelsesforsker læser jeg bogen som et forsøg på at stille skarpt på et aspekt af uddannelsesforskningen, som ellers ikke levnes megen plads - som forfatterne selv pointerer. En insisteren på, at uddannelsessammenhænge kan og skal belyses med blik for, hvad der følelsesmæssigt er på spil, finder jeg både spændende og vigtig. Bidragene $\mathrm{i}$ bogen handler om og diskuterer tilstedeværelsen af følelser på en ret forskellig og ikke 
alle steder lige vellykket måde. De empiriske nedslag synes velvalgte og relevante, og bliver bærende for diskussionerne (eller refleksionerne, som de selv siger).

Som underviser og uddannelsesansvarlig synes jeg bogen fremstår som et noget abstrakt bidrag til undervisningspraksis. Her får man ikke tilstrækkelig indsigt i de læringsmiljøer, som analyserne trækker på. Som praktiker er der derfor ikke så meget at hente til inspiration.

Konkluderende mener jeg, at indsatsen med at arbejde analytisk med tilstedeværelsen af følelser i læring, undervisning og uddannelsen er prisværdig. Som forfatterne selv siger, er dette arbejde et forsøg på at sætte sådant arbejde på dagsordenen og danne afsæt til at lave mere uddybende studier og analyser. Det er velkomment.

Bogen indeholder følgende kapitler:

The Notion of Emotion in Educational Settings When Learning to Become Innovative and Creative (Birthe Lund). I dette kapitel analyseres en gruppe gymnasieelevers følelses- og adfærdsmæssige reaktioner i forhold til den pædagogiske praksis i relation til rollespil med henblik på at udvikle innovative og kreative medborgere i Nordjylland. I kapitlet konkluderes det, at eleverne både oplever usikkerhed og stort engagement, når de mødes med det uforudsigelige i sådanne kreative og innovative processer. Det problematiseres at undervisning ofte tilrettelægges med henblik på at undgå sådanne usikkerheder og derfor også risikerer at forhindre udviklingen af engagement og kreativitet.

Emotions and Learning in Arts-Based Practices of Emotional I nnovation (Tatiana Chemi and J ulie Borup J ensen). Dette kapitel følger et forløb, hvor en gruppe undervisere på en professionshøjskole arbejder med at implementere kunst og æstetik som en del af deres undervisningspraksis. I analysen af denne proces skelnes der mellem negative og positive responser på arbejdet hos både undervisere og studerende. Kapitlet konkluderer, at kunst og æstetisk baseret undervisning gør det muligt at få øje på ellers skjulte lære- og erfaringsprocesser, både for studerende og undervisere. Undervisere synes i særlig grad at være sensitive i forhold til de studerendes (især) positive responser på undervisningen. Analysen peger fremad mod behovet for yderligere forskning i, hvordan følelser udtrykkes og modtages i læringsrum, hvor der arbejdes med kunstbaseret og æstetisk undervisningspraksis.

Gross National Happiness in Bhutanese Education (Lone Krogh and Krishna Prassad Giri). Dette kapitel diskuterer, hvordan man i Bhutan implementerer 'happiness' som et parameter for politisk og social vækst og dermed som et overordnet mål for landets uddannelsespolitik og praksis. Kapitlet rejser spørgsmålene, hvorvidt indførelse af 'Gross National Happiness' i sig selv skaber glæde, og om det i virkeligheden er for stor en udfordring for uddannelserne at implementere dette overordnede mål i alle fag. I kapitlet diskuteres det, hvordan man som uddannelser balancerer mellem kravet om at udvikle denne særlige nationale identitet baseret på harmoni og 'happiness', og kravet om at udvikle uddannelserne, så de lever op til globale mål og krav, som baseres på andre parametre og forståelser af vækst. Konklusionen er, at man med tilstrækkelig opmærksomhed på behovet for kontinuerligt at uddanne lærerne til at klare opgaven, godt kan opnå både 'happiness' og global vækst.

\footnotetext{
How Does It Feel to Become a Master's Student? Boundary Crossing and Emotions Related to Understanding a New Educational Context (Annie Aarup Jensen). I dette kapitel analyseres modne studerendes møde med en akademisk uddannelses- og læringskultur, når de påbegynder kandidatuddannelse efter endt professionsbacheloruddannelse og nogle års erhvervsaktivitet. Analysen af disse studerendes følelsesmæssige reaktioner på mødet med en akademisk læringskultur bygger på den obligatori-
} 
ske 'studieudviklingsplan', som dels består af en skriftlig rapport og dels af en dialog med en anden studerende. De skriftlige produkter viser, at de modne studerende er på hårdt følelsesmæssigt arbejde i mødet med den akademiske læringskultur. I kapitlet konkluderes det, at de ofte oplever det som om, de overlades til selv at skabe mening i overgangen, hvilket betyder, at de oplever det som et individuelt problem. Det skaber oplevelser af ensomhed og angst for at fejle. Det anbefales at der fokuseres på den institutionelle logik, som skaber denne oplevelse, og at der sættes ind med understøttelse af disse studerendes overgange i forhold til det institutionelle problem.

Emotions in the Classroom: The Powerful Role of Classroom Relationships (Sarah L. Grams and Roman J urowetzki). I dette kapitel præsenteres et surveybaseret studie af sammenhængen mellem læringsglæden og elev-lærerrelationen hos tyske elever i alderen 10-13 år. Hypotesen bag undersøgelsen er, at der er en sammenhæng mellem elevernes oplevede glæde ved læring og deres oplevelse af en positiv elev-lærerrelation. Denne hypotese bekræftes i undersøgelsen, idet det slås fast, at læreren har en signifikant betydning for etableringen af et gunstigt læringsmiljø og for elevernes læringsudbytte. Det slås fast, at det er ønskeligt, at der rettes større opmærksomhed mod etableringen af socialt og følelsesmæssigt understøttende læringsmiljøer.

A Comparative Study of Students' Perceptions of Humor in Learning Creative Design between China and Denmark (Chunfang Zhou, Tatiana Chemi and Birthe Lund). Studiet, som præsenteres i dette kapitel, er et komparativt studie af studerendes brug og opfattelse af humor i gruppearbejde på uddannelser i industrielt design i henholdsvis Kina og Danmark. Studiet baserer sig på kvalitative interviews med studerende, som er involveret i gruppearbejde omkring deres uddannelse - i Danmark er det gruppearbejde, som er en del af den pædagogiske metode, i Kina er gruppearbejdet især relateret til samarbejder med eksterne virksomheder og organisationer. Studiet konkluderer, at når studerende i begge lande er positivt stemte i forhold til deres kreative arbejde, kommer det til udtryk i form af humor. Dog er der den forskel, at når danske studerende benytter humor, ser de det som en væsentlig del af den kreative proces, mens de kinesiske studerende opfatter humor som et redskab til at skabe gode individuelle relationer ind i gruppen. Analysen peger på, at vejledere generelt set skal være mere opmærksomme på brugen af humor i gruppearbejde. I Kina bør vejledere være mere understøttende i forhold til at etablere en humoristisk atmosfære i grupperne, da humoren betragtes som en grundpille i designeres sociale identitet og i udviklingen af en kreativ industri. 